DOI: $10.31393 /$ reports-vnmedical-2019-23(4)-28

UDC: $616.24-08: 616-036.1+572.7: 615.014 .425$

\title{
CLINICAL-MORPHOLOGICAL STUDY OF LUNG DISEASES IN BASIC TREATMENT WITH THE USE OF ANTIOXIDANTS OF DIFFERENT ORIGIN AND WITHOUT
}

\section{Korol T.M., Ahafonov K.M.}

National Pirogov Memorial Medical University, Vinnytsya (Pirogov st. 56, Vinnytsya, Ukraine, 21018)

Received: September 27, 2019; Accepted: October 29, 2019

Responsible for correspondence: e-mail: kostya.agafonov2013@gmail.com

\begin{abstract}
Annotation. The purpose of the work is to analyze contemporary views on the morphological changes of lung tissue in inflammatory disease in the clinical and experimental conditions and results of correction by using the antioxidants. The analysis is based in a review if foreign articles for 2014-2019, using the scientometric databases PubMed, Web of Science and Google Scholar. According to the latest data from WHO and WORLD HEALTH RANKINGS 5-year mortality rate of such disease as COPD typically ranges from $40 \%$ to $70 \%$, depending on disease severity, while the 2-year mortality rate for people with severe COPD is about $50 \%$. We know that almost $90 \%$ of COPD deaths occur in low- and middle-income countries such as Ukraine. Thereby mortality rate from lung tissue diseases in Ukraine is $11.11 \%$. These diseases often accompanied by inflammation and oxidative stress. The last can cause mitochondrial dysfunction, dynamic changes and mitophagy impairment, which leads to increase the number of superoxide anions, hydrogen peroxide etc., inflammatory responses and cellular senescence. They all play important roles in the pathogenesis of chronic lung diseases, such as chronic obstructive pulmonary disease, pulmonary fibrosis and bronchopulmonary dysplasia. Many studies in vitro approved the role of antioxidants in the decreasing of the degree of morphological changes: inflammatory cells infiltration and alveolar edema, permeability and inflammation. In vivo disease development is mainly related to the many conditions, but closely to its severity and possible of combination with other diseases. Thereby treatment of such diseases by using e.g. leaves extract of different herbs can be prescribe to ameliorate the level of reactive oxygen species and decrease the possible cell injure made by antiinflammatory medicines.
\end{abstract}

Keywords: reactive oxygen species, antioxidants, acute lung injury.

Frequency of mortality from lung tissue diseases in Ukraine is 11.11 that is our rank 168th according to WORLD HEALTH RANKINGS (2017). Although there are many questions concerning developing lung tissue diseases, it is progressing and relation of impact of oxidative stress on mortality rate and morphological changes. Accordingly these we can highlight the main causes of formation of reactive oxygen, peroxide radicals and others products of cell metabolism.

T. Finkel and co-authors (2015) discovered that mitochondria plays important part as a source of mitochondrial reactive oxygen (mtROS) under the different conditions in humans during oxidative phosphorylation because of the leakage of activated oxygen. Additionally, calcium overload in the mitochondrial matrix enhances the generation of mitochondrial ROS (mtROS) and the release of cytochrome c, resulting in apoptosis and cell death [8]. Physiological processes, which activated as moderators of increased mtROS level, protect against the adverse effects of various cellular stresses and infection [13]. However, their activity depends on the ability of cell to generate ATP, enzyme level and activity. Other authors discovered there is accumulating evidence that the mitochondria has a nonenergetic role in regulating metabolism, apoptosis, innate immunity, inflammatory responses and aging [9]. All of these processes are involved in the pathogenesis of chronic lung diseases, such as chronic obstructive pulmonary disease (COPD), pulmonary fibrosis and bronchopulmonary dysplasia (BPD) [34].

Estimates are that by the year 2030, COPD will rise to the 3rd leading cause of death worldwide unless urgent action isn't taken to reduce tobacco use [32]. In Ukraine major changes in COPD mortality in 1980-2010 were concurrent with changing economic conditions and could only partially be tobacco-related [3]. COPD is characterized by a persistent airflow limitation and lung function decline, where cigarette smoke (CS) is the main etiological factor. CS contains more than 5,000 different chemicals, many of which are oxidants. It is estimated that each puff may contain $>1015$ free radicals that deplete endogenous antioxidants and tilt the delicate balance in favor of an oxidative stress (OS). The pathogenesis of COPD involves a variety of cellular processes, including oxidative stress, inflammatory responses and cellular senescence [11, 34]. Histopathological COPD is characterized by respiratory (smoker's) bronchiolitis, inflammation and fibrosis of terminal and respiratory bronchioles, reduction in terminal bronchioles, squamous metaplasia and so on [4]. Ahmad T. and co-authors discovered the defects of mitochondria by the methods by which the quality of it is controlled - mitophagy, which has been shown to be involved in the pathogenesis of COPD. Authors have shown that cigarette smoke impairs mitophagy, leading to incomplete degradation of damaged mitochondria [1]. These damaged mitochondria may accumulate in the perinuclear region where generating excessive mtROS leads to nuclear DNA damage and subsequent cellular senescence. This is corroborated by the finding that restoration of mitophagy by the overexpression of Parkin reduces cigarette smoke-induced DNA damage and cellular senescence when used in 
combination with an mtROS scavenger [1, 34]. Indeed, the levels of Parkin are reduced in lung tissues of COPD patients compared with those of non-smokers and smokers [1, 12, 34], which further confirms the impairment of mitophagy in COPD. Other authors admitted that severe stress derived from high concentrations of cigarette smoke induces necroptosis (i.e. necrosis and apoptosis), which is mediated by PINK1-induced mitophagy [20,34]. To attenuate the changes of lung tissue after impact of cigarettes smoke and decrease the oxidative stress Ahmad Husari and co-authors (2016) used supplementation of pomegranate juice (PJ) [11]. One month of sublimation of PJ resulted in limited destruction of the normal alveolar architecture and decreased level of TNF- $\alpha$; third month of sublimation reversed the emphysematous changes noted histologically and attenuated the increase in linear intercept distance [11]. The in vitro study showed that PJ supplementation significantly suppressed CS-induced reactive oxygen species (ROS) [11]. Another study admitted the role of Atorvastatin and Simvastatin in enhancing mouse lung repair after CS induced lung tissue injury. Pinho-Ribeiro V. and coauthors observed that morphologically changes of lung tissue and noted the same pattern of total cell numbers was observed in macrophages, but not in neutrophils, which were higher in CS [25].

Mechanical ventilation (MV) as a method of breath support in COPD closely involved in developing ventilator-induced lung injury (VILI). Last is characterized by a disruption of the alveolar-capillary barrier which increases permeability, thus causing edema, inflammatory leukocyte infiltration (mainly neutrophils), and hemorrhage [30]. As follows, the correction of ROS and mtROS level in COPD opens the new ways of increasing patient's life level. Bixin induces the expression of nuclear factor-erythroid-related factor 2 (NRF2) and its downstream targets in lung tissues of Nrf2+/+ mice. More importantly, bixin pretreatment restored normal lung morphology and alleviated MV-induced inflammation and oxidative stress, these effects seem to be dependent on NRF2 signaling since Nrf2-/- mice did not benefit from bixin pretreatment [30]. Although the use of direct antioxidants, like $\mathrm{N}$-acetyl cysteine (NAC), has some degree of beneficial effects but Shasha Tao and co-authors suggested that activating the body's own defensive responses through upregulation of the NRF2 pathway in combination with low tidal ventilator strategies will result in greater benefits for the patients $[30,23]$. Another histological study revealed that inflammatory cells infiltration and alveolar edema, permeability and inflammation induced by ventilation were significantly severe in VILI as compared to other groups treated by curcumin. In addition, curcumin ameliorates level of tumor necrosis factor (TNF)- $\alpha$ and NF- $\beta B$ activity which were significantly increased in VILI group [31]. Mairead Hayes and co-authors observed that human mesenchymal stem cells (hMSCs) improved lung compliance, reducing alveolar edema, and restoring lung architecture. hMSCs attenuated lung inflammation, decreasing alveolar cellular infiltration, and decreasing cytokine-induced neutrophil chemoattractant-1 and interleukin- 6 while increasing keratinocyte growth factor concentrations, as result level of ROS and mtROS [10].

The outcome of progressing of chronic inflammation of lung tissue, excessive number of mesenchymal cells near inflammatory area, dysfunction of cells will lead to excessive accumulation of macromolecules in extracellular matrix, thereby cause the scar and loss of elasticity in lungs. Both fibroblasts and myofibroblasts are the principal effectors cells of the lung for the generation of extracellular matrix [33]. M. Bueno and co-authors (2015) have highlighted the importance of mitochondrial function and mitophagy in the pathogenesis of lung fibrosis. It has been shown that damaged or dysfunctional mitochondria accumulate in alveolar epithelial cells of patients with idiopathic pulmonary fibrosis [5]. However, it is not clear whether mitochondrial dysfunction and mitophagy impairment occur in (myo) fibroblasts during pulmonary fibrosis. Also further studies are required to determine how mitochondrial dysfunction in lung epithelial cells interacts with (myo)fibroblasts, leading to fibrogenesis [34]. It has been shown that once released mtDNA recruits peripheral blood mononuclear cells and stimulates epithelial cells to generate TGF- $\beta 1$ [16]. Targeting mtDNA by DNase I protects against paraquat-induced pulmonary fibrosis [16]. Interestingly, TGF- $\beta 1$ increases the number of mitochondria, mitochondria-specific proteins, voltage-dependent anion channels, adenine nucleotide transporter and mtDNA content, whereas mitochondrial oxidative phosphorylation and mitophagy are impaired during fibroblast differentiation [21, 27, 34]. Authors proposed that mitochondrial biogenesis is needed for fibroblast differentiation that this effect is further promoted by mitophagy impairment and damaged mitochondria during fibrogenesis. However, it is not clear how TGF- $\beta 1$ alters mitochondrial homeostasis, inducing the accumulation of damaged mitochondria and subsequent fibrogenesis [34]. M. Bueno et al. (2015) and M. L. Sosulski et al. (2015) admitted in relation aging in developing lung fibrosis. They has shown that it participate in the pathogenesis of lung fibrosis as both mitochondria respiration and mitophagy are compromised in aging, whereas the levels of the mitochondrial biogenesis marker PGC1 $\alpha$, mitochondrial transcription factor A TFAM and mitochondrial gene cytochrome $c$ are comparable between young and old mouse lungs [5, 27, 34].

Reducing the effects of increased production of oxidative stress components that enhance the development of pulmonary fibrosis remains it is actuality. The treatment of Phyllanthus emblica leaves (PELE) to $\mathrm{CCl} 4$ exposed rat demonstrated strong repairing ability as manifested by the elevation in activity level of catalase, superoxide dismutase, glutathione peroxidase and GSH in the pulmonary samples of rat. PELE was also able to ameliorate the oxidative injuries induced with $\mathrm{CCl} 4$ and decreased the elevated level of TBARS, $\mathrm{H} 2 \mathrm{O} 2$ and nitric oxide in lung samples of rat. The repairing abilities of PELE on the histopathology of 
lungs showed normal alveoli with explicit alveolar spaces and bronchioles having slight cell degeneration, intraalveolar septa thickening were observed in most lung regions [29].

In the modeling experimental condition that will cause the development of pulmonary fibrosis mainly associated with bleomycin. It was found that Nrf2 and its downstream antioxidant factors are involved in the pathogenesis of IPF $[18,26]$. Nrf2 agonist attenuated pulmonary fibrosis induced by bleomycin (BLM) via the oxide level in lung tissue [15]. Y Liu and co-authors (2017) demonstrated that Bach1 knockout inhibited the progression of BLM-induced pulmonary fibrosis by regulating the expressions of Nrf2 and its downstream anti-oxidant factors [17]. The changes in lung tissue induced by bleomycin characterized by alveolar edema, a significant increase in septum width and increased inflammatory cells infiltration on 14 days and the alveolus collapsed or disappeared, the structure was markedly damaged, and a large number of inflammatory cells and fibroblasts were infiltrated on 42 days respectively. Administration of pirfenidone (PED) for 4 weeks ameliorated the inflammatory infiltration, the damaged structure in lung tissue and fibrosis as compared to that of the BLM group [18]. Other study demonstrated that celastrol also reduces inflammation in BLM-induced rats as evidenced by decrease in the expressions of mast cells, Tumor necrosis factor-alpha (TNF- $\alpha$ ) and matrix metalloproteinases (MMPs) 2 and 9 [7]. O. Khazri and coauthors (2016) admitted the role of grape seed and skin extract properties that could find potential application in the protection against bleomycin-induced lung fibrosis [14].

Another experimental model that initiate fibrosis close linked to lipopolysaccharide (LPS). Toshio Suzuki and coauthors (2017) presented hypothesis in which that stated that LPS exposure leads to pulmonary fibrosis via endothelialto-mesenchymal transition (EndMT). Given that one of the main initial targets of endotoxins is vascular endothelial cells especially in case of acute respiratory distress syndrome from extra-pulmonary origin $[6,22,28]$, EndMT could thus be closely involved in the pathogenesis of pulmonary fibrosis after systemic endotoxemic injury [28]. Morphological examination following LPS induction revealed that several histopathological alterations, including cell structure destruction, neutrophil infiltration, alveolar wall thickening and lung edema, had occurred in the lung tissue [35]. The development of morphological changes may be diminished if antioxidants are used. G.F. Zhu and co-authors (2015) provided in vitro regular LPS induction, a significant increase was observed in the myeloperoxidase (MPO) activity and the number of

\section{References}

1. Ahmad, T., Sundar, I. K., Lerner, C. A., Gerloff, J., Tormos, A. M., Yao, H., \& Rahman, I. (2015). Impaired mitophagy leads to cigarette smoke stress-induced cellular senescence: implications for chronic obstructive pulmonary disease. The FASEB Journal, 29(7), 2912-2929. doi:10.1096/fj.14-268276. neutrophils in the lung tissues, compared with the phosphate buffered saline-treated (PBS) healthy control group [35]. Toshio Suzuki and co-authors (2017) in vitro showed that in model of pulmonary fibrosis after systemic endotoxemic injury, CD26/dipeptidyl peptidase 4 (DPP-4) expressions is upregulated in pulmonary vascular endothelial cells (PVECs) in both the presence and absence of immune cells. Vildagliptin treatment attenuated the accumulation of DPP-4 in PVECs, and was associated with an inhibition of fibrotic change and reduced EndMTcells in lungs. It can be result of direct action of DPP-4 inhibitors on ROS production in PVECs and attenuating EndMT [30]. Also increase in MPO activity and neutrophils was eliminated by the eriodictyol pretreatment, as compared with the LPS-induced ALI [35]

In other study Naif O. Al-Harbi and co-authors (2015) discovered the role of riboflavin in comparing to dexamethasone as a method of attenuation lipopolysaccharide-induced lung injury. Cellular LPSinduced changes including interstitial edema, hemorrhage, infiltration of PMNs, etc., which were reversed by riboflavin (100 mg/kg, p.o.) administration, which showed similar protective effects as dexamethasone (1 $\mathrm{mg} / \mathrm{kg}$, p.o.) [2].

C. Luo and co-authors (2015) evaluated the role of intestinal ischemia-reperfusion (IIR) that can resulted in severe damage to the lungs, with collapse of the alveoli, interstitial edema, haemorrhage in the alveoli and mesenchyme, neutrophil infiltration and atelectasis. But they discovered that pretreatment with sevoflurane SEV and apocynin (AP) significantly prevented the lung damage induced by IIR in the way of: protecting type II alveolar epithelial cells from the injury induced by IIR and mast cell degranulation, inhibiting inflammatory responses and decreasing the level of ROS [19].

\section{Conclusions and prospects for future development}

1. Overall we can state the widespread prevalence of pulmonary tissue diseases and their possible complications caused by oxidative stress and inflammation most studies in vitro approved the role of antioxidants in the decreasing of the degree of morphological changes: inflammatory cells infiltration and alveolar edema, permeability and inflammation. In vivo the role of antioxidants, compared to anti-inflammatory medicines have the same results and can be prescribe to the patients to ameliorate the pathognomonic signs or prevent them.

Therefore importance of including in treatment of these diseases antioxidants remains an important recommendation.

2. Al-Harbi, N. O., Imam, F., Nadeem, A., Al-Harbi, M. M., Korashy, H. M., Sayed-Ahmed, M. M., ... Bahashwan, S. (2015). Riboflavin attenuates lipopolysaccharide-induced lung injury in rats. Toxicology mechanisms and methods, 25(5), 417423. doi:10.3109/15376516.2015.1045662. 
3. Andreeva, T. I., \& Krasovsky, K. S. (2016). COPD Morbidity and Mortality in Ukraine after Tobacco Control Policies Implementation. Chronic Obstructive Pulmonary Diseases, 1, 3. doi: $10.21767 / 2572-5548.100003$.

4. Berg, K., \& Wright, J. L. (2016). The pathology of chronic obstructive pulmonary disease: progress in the 20th and 21st centuries. Archives of pathology \& laboratory medicine, 140(12), 1423-1428. DOI:10.5858/arpa.2015-0455-RS.

5. Bueno, M., Lai, Y. C., Romero, Y., Brands, J., Croix, C. M. S., Kamga, C., ... Mora, A. L. (2015). PINK1 deficiency impairs mitochondrial homeostasis and promotes lung fibrosis. The Journal of clinical investigation, 125(2), 521-538. doi:10.1172/ $\mathrm{JCl} 74942$

6. Choi, S. H., Hong, Z. Y., Nam, J. K., Lee, H. J., Jang, J., Yoo, R. J., ... Ji, Y. H. (2015). A hypoxia-induced vascular endothelialto-mesenchymal transition in development of radiation-induced pulmonary fibrosis. Clinical Cancer Research, 21(16), 37163726. doi: 10.1158/1078-0432.

7. Divya, T., Dineshbabu, V., Soumyakrishnan, S., Sureshkumar, A., \& Sudhandiran, G. (2016). Celastrol enhances Nrf2 mediated antioxidant enzymes and exhibits anti-fibrotic effect through regulation of collagen production against bleomycininduced pulmonary fibrosis. Chemico-biological interactions, 246, 52-62. doi:10.1016/j.cbi.2016.01.006.

8. Finkel, T., Menazza, S., Holmstrom, K. M., Parks, R. J., Liu, J., Sun, J., ... Murphy, E. (2015). The ins and outs of mitochondrial calcium. Circulation research, 116 (11), 1810-1819. doi:10.1161/CIRCRESAHA.116.305484.

9. Friedman, J. R., \& Nunnari, J. (2014). Mitochondrial form and function. Nature, 505(7483), 335-343. doi:10.1038/ nature12985.

10. Hayes, M., Masterson, C., Devaney, J., Barry, F., Elliman, S., O'Brien, T., ... Laffey, J. G. (2015). Therapeutic efficacy of human mesenchymal stromal cells in the repair of established ventilator-induced lung injury in the rat. Anesthesiology: The Journal of the American Society of Anesthesiologists, 122(2), 363-373. doi:10.1097/ALN.0000000000000545.

11. Husari, A., Hashem, Y., Bitar, H., Dbaibo, G., Zaatari, G., \& El Sabban, M. (2016). Antioxidant activity of pomegranate juice reduces emphysematous changes and injury secondary to cigarette smoke in an animal model and human alveolar cells. International journal of chronic obstructive pulmonary disease, 11, 227. doi: 10.2147/COPD.S97027.

12. Ito, S., Araya, J., Kurita, Y., Kobayashi, K., Takasaka, N., Yoshida, M., .... Kojima, J. (2015). PARK2-mediated mitophagy is involved in regulation of HBEC senescence in COPD pathogenesis. Autophagy, 11(3), 547-559. doi:10.1080/ 15548627.2015.1017190

13. Katz, A., Hernandez, A., Caballero, D. M. R., Briceno, J. F. B., Amezquita, L. V. R., Kosterina, N., ... Westerblad, H. (2014). Effects of $\mathrm{N}$-acetylcysteine on isolated mouse skeletal muscle: contractile properties, temperature dependence, and metabolism. Pflugers Archiv-European Journal of Physiology, 466(3), 577-585. doi:10.1007/s00424-013-1331-z.

14. Khazri, O., Charradi, K., Limam, F., El May, M. V., \& Aouani, E. (2016). Grape seed and skin extract protects against bleomycin-induced oxidative stress in rat lung. Biomedicine \& Pharmacotherapy, 81, 242-249. doi:10.1016/ j.biopha.2016.04.004.

15. Kikuchi, N., Ishii, Y., Morishima, Y., Yageta, Y., Haraguchi, N., Itoh, K., ... Hizawa, N. (2010). Nrf2 protects against pulmonary fibrosis by regulating the lung oxidant level and Th1/Th2 balance. Respiratory research, 11(1), 31. doi:10.1186/14659921-11-31.

16. Li, G., Yuzhen, L., Yi, C., Xiaoxiang, C., Wei, Z., Changqing, Z., \& Shuang, Y. (2015). DNasel protects against Paraquatinduced acute lung injury and pulmonary fibrosis mediated by mitochondrial DNA. BioMed research international, 2015. doi:10.1155/2015/386952.

17. Liu, Y., \& Zheng, Y. (2017). Bach1 siRNA attenuates bleomycininduced pulmonary fibrosis by modulating oxidative stress in mice. International journal of molecular medicine, 39(1), 91100. doi:10.3892/ijmm.2016.2823.

18. Liu, Y., Lu, F., Kang, L., Wang, Z., \& Wang, Y. (2017). Pirfenidone attenuates bleomycin-induced pulmonary fibrosis in mice by regulating Nrf2/Bach1 equilibrium. BMC pulmonary medicine, 17(1), 63. doi 10.1186/s12890-017-0405-7.

19. Luo, C., Yuan, D., Zhao, W., Chen, H., Luo, G., Su, G., \& Hei, Z. (2015). Sevoflurane ameliorates intestinal ischemiareperfusion-induced lung injury by inhibiting the synergistic action between mast cell activation and oxidative stress. Molecular medicine reports, 12(1), 1082-1090. doi:10.3892/ mmr.2015.3527.

20. Mizumura, K., Cloonan, S. M., Nakahira, K., Bhashyam, A. R., Cervo, M., Kitada, T., ... Hashimoto, S. (2014). Mitophagydependent necroptosis contributes to the pathogenesis of COPD. The Journal of clinical investigation, 124(9), 39874003. doi:10.1172/JCl74985.

21. Negmadjanov, U., Godic, Z., Rizvi, F., Emelyanova, L., Ross, G., Richards, J., ... Jahangir, A. (2015). TGF- $\beta 1$-mediated differentiation of fibroblasts is associated with increased mitochondrial content and cellular respiration. PloS one, 10(4), e0123046. doi:10.1371/journal.pone.0123046.

22. Nickols, J., Obiako, B., Ramila, K. C., Putinta, K., Schilling, S., \& Sayner, S. L. (2015). Lipopolysaccharide-induced pulmonary endothelial barrier disruption and lung edema: critical role for bicarbonate stimulation of AC10. American Journal of Physiology-Lung Cellular and Molecular Physiology, 309(12), L1430-L1437. doi:10.1152/ajplung.00067.2015.

23. Papaiahgari, S., Yerrapureddy, A., Reddy, S. R., Reddy, N. M., Dodd-O, J. M., Crow, M. T., ... Reddy S. P. (2007). Genetic and pharmacologic evidence links oxidative stress to ventilatorinduced lung injury in mice. American journal of respiratory and critical care medicine, 176(12), 1222-1235. doi:10.1164/ rccm.200701-0600C.

24. Patel, A. S., Song, J. W., Chu, S. G., Mizumura, K., Osorio, J. C., Shi, Y., ... Morse, D. (2015). Epithelial cell mitochondrial dysfunction and PINK1 are induced by transforming growth factor-beta1 in pulmonary fibrosis. PloS one, 10(3), e0121246. doi:10.1371/journal.pone.0121246.

25. Pinho-Ribeiro, V., Melo, A. C., Kennedy-Feitosa, E., Graca-Reis, A., Barroso, M. V., Cattani-Cavalieri, I., ... Lanzetti, M. (2017). Atorvastatin and simvastatin promoted mouse lung repair after cigarette smoke-induced emphysema. Inflammation, 40(3), 965-979. doi: 10.1007/s107.

26. Santos-Silva, M. A., Pires, K. M. P., Trajano, E. T. L., Martins, V., Nesi, R. T., Benjamin, C. F., ... Porto, L. C. (2012). Redox imbalance and pulmonary function in bleomycin-induced fibrosis in C57BL/6, DBA/2, and BALB/c mice. Toxicologic pathology, 40(5), 731-741. doi:10.1177/0192623312441404.

27. Sosulski, M. L., Gongora, R., Danchuk, S., Dong, C., Luo, F., \& Sanchez, C. G. (2015). Deregulation of selective autophagy during aging and pulmonary fibrosis: the role of TGF $\beta 1$. Aging cell, 14(5), 774-783. doi:10.1111/acel.12357.

28. Suzuki, T., Tada, Y., Gladson, S., Nishimura, R., Shimomura, I., Karasawa, S., ... West, J. (2017). Vildagliptin ameliorates pulmonary fibrosis in lipopolysaccharide-induced lung injury by inhibiting endothelial-to-mesenchymal transition. Respiratory research, 18(1), 177. doi:10.1186/s12931-017-0660-4.

29. Tahir, I., Khan, M. R., Shah, N. A., \& Aftab, M. (2016). Evaluation of phytochemicals, antioxidant activity and amelioration of pulmonary fibrosis with Phyllanthus emblica leaves. BMC complementary and alternative medicine, 16(1), 406. doi:10.1186/s12906-016-1387-3. 
30. Tao, S., De La Vega, M. R., Quijada, H., Wondrak, G. T., Wang, T., Garcia, J. G., \& Zhang, D. D. (2016). Bixin protects mice against ventilation-induced lung injury in an NRF2-dependent manner. Scientific reports, 6, 18760. doi:10.1038/srep18760.

31. Wang, X., An, X., Wang, X., Bao, C., Li, J., Yang, D., \& Bai, C. (2018). Curcumin ameliorated ventilator-induced lung injury in rats. Biomedicine \& Pharmacotherapy, 98, 754-761. doi:10.1016/j.biopha.2017.12.100.

32. World Health Organization (2019). WHO burden of Chronic Obstruct Pulmonary Disease.

33. Yao, H. W., \& Li, J. (2015). Epigenetic modifications in fibrotic diseases: implications for pathogenesis and pharmacological targets. Journal of Pharmacology and Experimental Therapeutics, 352(1), 2-13. doi:10.1124/jpet.114.219816.

34. Yue, L., \& Yao, H. (2016). Mitochondrial dysfunction in inflammatory responses and cellular senescence: pathogenesis and pharmacological targets for chronic lung diseases. British journal of pharmacology, 173(15), 23052318. doi:10.1111/bph.13518.

35.Zhu, G. F., Guo, H. J., Huang, Y., Wu, C. T., \& Zhang, X. F. (2015). Eriodictyol, a plant flavonoid, attenuates LPS-induced acute lung injury through its antioxidative and anti-inflammatory activity. Experimental and therapeutic medicine, 10(6), 22592266. doi:10.3892/etm.2015.2827.

\section{КЛІНІКО-МОРФОЛОГІЧНЕ ДОСЛІДЖЕННЯ ЛЕГЕНЕВИХ ЗАХВОРЮВАНЬ ПРИ БАЗИСНОМУ ЛІКУВАННІ 3 ВИКОРИСТАННЯМ} АНТИОКСИДАНТІВ РІЗНОГО ПОХОДЖЕННЯ ТА БЕЗ НИХ

Король Т.М., Агафонов К.М.

Анотація. Мета роботи - аналіз сучасних поглядів на морфологічні зміни легеневої тканини при запальних захворюваннях у клінічних та експериментальних умовах і результати їх корекції за допомогою антиоксидантів. Аналіз грунтується на огляді закордонних статей за 2014-2019 роки з використанням наукометричних баз даних PubMed, Web of Science та Google Scholar. Відповідно до останніх даних BООз та WORLD HEALTH RANKINGS 5-річна смертність від такої хвороби як хронічне обструктивне захворювання легень (ХОЗЛ) зазвичай коливається від 40\% до 70\%, залежно від ступеня тяжкості захворювання, тоді як 2-річний рівень смертності для людей із важким перебігом ХОзЛ становить близько 50\%. Відомо, що майже 90\% смертей від ХОЗЛ припадає на країни з низьким та середнім рівнем доходу, до яких відносять і Україну. Рівень смертності від захворювань легеневої тканини в Україні становить 11,11\%. Ці захворювання часто супроводжуються запаленням і окислювальним стресом. Останнє може спричинити дисфункцію мітохондрій, динамічні зміни та порушення мітофрасії, що призводить до збільшення кількості супероксидних аніонів, перекису водню тощо, запальних реакцій та клітинного старіння. Всі вони відіграють важливу роль у патогенезі хронічних захворювань легенів, таких як ХОЗЛ, легеневий фіброз та бронхолегенева дисплазія. Багато досліджень іn vitro підтвердили роль антиоксидантів у зниженні ступеня морфологічних змін: інфільтрації запальними клітинами та набряку альвеол, підвищення проникності та запалення. Розвиток хвороби in vivo в основному пов'язаний з безліччю станів, залежних від їі тяжкості та можливого поєднання з іншими захворюваннями. У лікуванні таких захворювань застосовують, наприклад, екстракт листя різних трав, який може бути призначений для поліпшення рівня реактивних видів кисню та зменшення можливої травми клітин, викликаної протизапальними препаратами.

Ключові слова: реактивні види кисню, антиоксиданти, гострі травми легень.

\section{КЛИНИКО-МОРФОЛОГИЧЕСКОЕ ИССЛЕДОВАНИЕ ЛЕГОЧНЫХ ЗАБОЛЕВАНИЙ ПРИ БАЗИСНОМ ЛЕЧЕНИИ С ИСПОЛЬЗОВАНИЕМ АНТИОКСИДАНТОВ РАЗЛИЧНОГО ПРОИСХОЖДЕНИЯ И БЕЗ НИХ \\ Король Т.М., Агафонов К.М.}

Аннотация. Цель работы - анализ современных взглядов на морфологические изменения легочной ткани при воспалительных заболеваниях в клинических и экспериментальных условиях и результаты коррекции с помощью антиоксидантов. Анализ основывается на обзоре зарубежных статей за 2014-2019 годы с использованием наукометрических баз данных PubMed, Web of Science u Google Scholar. Согласно последним данным BO3 и WORLD HEALTH RANKINGS 5-летняя смертность от такой болезни как ХОБЛ обычно колеблется от 40\% до 70\% в зависимости от степени тяжести заболевания, тогда как 2-летний уровень смертности для людей с тяжелым течением ХОБЛ составляет около 50\%. Известно, что почти 90\% смертей от ХОБЛ приходится на страны с низким и средним уровнем дохода, такие как Украина. Уровень смертности от заболеваний легочной ткани в Украине составляет 11,11\%. Эти заболевания часто сопровождаются воспалением и окислительным стрессом. Последнее может привести к дисфункции митохондрий, динамических изменений и нарушению митофрагии, что приводит к увеличению количества супероксидных анионов, перекиси водорода и т.п., воспалительных реакций и клеточного старения. Все они играют важную роль в патогенезе хронических заболеваний легких, таких как хроническая обструктивная болезнь легких, легочный фиброз и бронхолегочная дисплазия. Многие исследования in vitro подтвердили роль антиоксидантов в снижении степени морфологических изменений: инфильтрации воспалительными клетками и отека альвеол, повышении проницаемости и воспаления. Развитие болезни іп vіvо в основном связано с множеством состояний, зависимых к ее тяжести и возможного сочетания с другими заболеваниями. В лечении таких заболеваний применяют, например, экстракт листьев различных трав, который может быть назначен для улучшения уровня реактивных видов кислорода и уменьшения возможной травмы клеток, вызванной противовоспалительными препаратами.

Ключевые слова: активные фрормы кислорода, антиоксиданты, острые повреждения легких. 